\title{
Major government customer and management earnings forecasts
}

\author{
Agnes C. S. Cheng*, Wenli Huang and Shaojun Zhange
}

\author{
* Correspondence: afagnes@polyu. \\ edu.hk \\ School of Accounting and Finance, \\ Faculty of Business, The Hong Kong \\ Polytechnic University, Hung Hom, \\ Kowloon, Hong Kong
}

\begin{abstract}
This paper examines whether customer base composition in the US, that is, whether a firm's major customers are government entities or publicly traded companies, affects the properties of its management earnings forecasts (MEFs). Using a sample of 1168 MEFs from 1998 to 2014, we find that firms whose major customers are government entities (i.e., government suppliers) issue more precise and more accurate MEFs than firms whose major customers are public companies (i.e., corporate suppliers). Moreover, when managers disclose negative information to the market, earnings forecasts issued by government suppliers have greater price impact than those issued by corporate suppliers. Collectively, our empirical results suggest that having major government customers has a positive impact on the quality of MEFs.

Keywords: Customer-supplier relationship, Demand uncertainty, Government supplier, Information spillover, Management earnings forecasts (MEFs)
\end{abstract}

\section{Introduction}

The economic relationship between customers and suppliers has important implications for major corporate decision-making. For example, Kale and Shahrur (2007) and Banerjee et al. (2008) show that firms with a stronger customer-supplier relationship tend to maintain a lower debt ratio. Raman and Shahrur (2008) provide evidence that earnings management is used opportunistically to influence the perception of suppliers or customers about a firm's prospects. Hui et al. (2012) find that when a firm's suppliers or customers have greater bargaining power, the firm follows more conservative accounting practices and recognizes losses more quickly in its financial statements. Cen et al. (2017) document evidence that firms with a close customer-supplier relationship tend to engage in tax avoidance strategies that shift profits to tax haven subsidiaries and that tax benefits appear to explain such firms' organizational decisions. ${ }^{1}$

\footnotetext{
${ }^{1}$ Other studies have examined the effects of the customer-supplier relationship on contract design (Costello 2013), dividend policy (Wang 2012), cash holdings (Itzkowitz 2013), mergers and acquisitions (Fee and Thomas 2004), ownership structure (Fee et al. 2006), operating efficiency (Ak and Patatoukas 2016), loan contract terms (Campello and Gao 2017; Kim et al. 2015), audit quality and fees (Dhaliwal et al. 2020; Krishnan et al. 2019), profitability (Hui et al. 2019; Irvine et al. 2016; Patatoukas 2012), and information transfer (Cheng and Eshleman 2014; Cohen and Frazzini 2008; Pandit et al. 2011; Radhakrishnan et al. 2014).
}

(c) The Author(s). 2020 Open Access This article is licensed under a Creative Commons Attribution 4.0 International License, which permits use, sharing, adaptation, distribution and reproduction in any medium or format, as long as you give appropriate credit to the original author(s) and the source, provide a link to the Creative Commons licence, and indicate if changes were made. The images or other third party material in this article are included in the article's Creative Commons licence, unless indicated otherwise in a credit line to the material. If material is not included in the article's Creative Commons licence and your intended use is not permitted by statutory regulation or exceeds the permitted use, you will need to obtain permission directly from the copyright holder. To view a copy of this licence, visit http://creativecommons.org/licenses/by/4.0/. 
An emerging literature documents evidence of the influence of the U.S. government as a major customer on suppliers' operating and financial outcomes. U.S. federal government spending constituted about $20 \%$ of U.S. gross domestic product (GDP) in the past four decades (Cohen and Li 2020). This is in line with the findings in Mills et al. (2013) and Dhaliwal et al. (2016) that U.S. federal government spending exceeded USD3.1 trillion between 2000 and 2008 and accounted for 23.2\% of GDP in 2011. Ellis et al. (2012) show that, for firms that report government entities as major customers, government customers account for $33.3 \%$ of their total sales. ${ }^{2}$ Banerjee et al. (2008) show that, for durable goods manufacturers, while sales to corporate customers have a significant negative effect on their debt ratio, sales to government customers have no such effect. Hui et al. (2012) and Dhaliwal et al. (2016) find that firms with major government customers tend to have more conservative accounting and lower cost of capital. Cohen and $\mathrm{Li}$ (2020) document that the concentration of major government customers has a positive effect on supplier profitability, whereas the concentration of major corporate customers has a negative effect.

Two recent studies suggest that the customer-supplier relationship affects suppliers' decision to provide management guidance. Samuels (in press) argues that a supplier that contracts with U.S. government entities should improve its internal information process in order to meet government contractual requirements. The author finds that government suppliers release more timely financial reports and issue management forecasts more frequently, which is consistent with the prediction in Verrecchia (1990) that high-quality internal information improves the quality of public disclosure. Crawford et al. (2020) argue that a close business relationship facilitates private information flow between customers and suppliers, and thus reduces customers' demand for public information. Empirically, they find that the frequency of supplier management earnings forecasts (MEFs) is negatively related to the degree of customer concentration. In contrast to Samuels (in press), their analysis focuses on the concentration of corporate customers and does not shed light on how major government customers may affect suppliers' public disclosure.

We extend this line of inquiry by investigating whether major government customers affect the quality of the MEFs that suppliers provide to the public. The financial reporting standard, SFAS No. 131, requires that firms include in their public financial report the sales to and the identity of any customer that comprises more than $10 \%$ of the firm's consolidated sales revenues, if losing the customer would have a material adverse impact on the firm (the so-called "major customer"). ${ }^{3}$ We distinguish firms whose major customers are exclusively U.S. federal, state, and local government entities (i.e., the government suppliers) from firms whose major customers are exclusively publicly listed companies (i.e., the corporate suppliers).

We argue that business transactions with government entities have unique features that improve the quality of government supplier MEFs. First, unlike corporations, government entities are much less likely to default or declare bankruptcy.

\footnotetext{
${ }^{2}$ They find that approximately $45 \%$ of public firms report at least one major customer, and among all firms that report major customer information, $13.4 \%$ of the major customers are government entities, while $49.6 \%$ and $16.7 \%$ are public and private firms, respectively. The names of the remaining $20.3 \%$ of reported customers were not disclosed.

${ }^{3}$ Ellis et al. (2012) provide a summary of the evolution of disclosure rules regarding customer information.
} 
They tend to offer longer-term procurement contracts and have more enforcement and bargaining power to monitor suppliers closely (Samuels, in press). Dhaliwal et al. (2016) obtain the U.S. government spending data for years 2003-2014 and find that approximately 31\% (in a U.S. dollar amount) of total federal procurement contracts have cost-plus pricing terms. Such pricing terms allow suppliers to shift operational risk to the government (Berrios 2006). When uncertainty about future customer demand is low, suppliers are able to plan and undertake customer-specific investments more efficiently (e.g., Chiu et al. 2019; Guiso and Parigi 1999). Cohen and $\mathrm{Li}$ (2020) find that government suppliers achieve greater efficiency in asset turnover and customer-specific selling, general, and administrative (SG\&A) investments, which leads to lower operational uncertainty and higher profitability. Second, government entities have objectives that are different from corporations, thus their decisions are often affected by non-business considerations, such as social welfare, environmental awareness, political lobbying, and campaign donations (Goldman et al. 2013). Firms contracting with government customers tend to face less competition in the product market and generate a large portion of their revenues from non-competitive procurement contracts (Mills et al. 2013). Third, government agencies follow a standard procurement process regulated by the Federal Acquisition Regulations (FARs) and require comprehensive information to assess whether a supplier has adequate financial resources to deliver the goods and services as expected. ${ }^{4}$ In order to meet the information demand by government procurement, government suppliers are likely to have a more efficient internal information process (Samuels, in press).

On the other hand, corporate customers may have greater demand for high-quality public disclosure from their suppliers than government customers. Government entities have great bargaining and enforcement power to obtain information from suppliers through private communications and need not rely on public disclosure (Chaney et al. 2011). Corporate customers may acquire private information from suppliers, but rely on public disclosure as a means to supplement private communications.

The quality of supplier management forecasts is jointly determined by their major customers' demand and their ability to forecast cash flows. While managers strive to meet major customers' demand for public information, their ability to forecast future earnings becomes the binding constraint on the quality of their earnings forecasts. Contracting with the government reduces demand uncertainty and competition in the product market, improves the internal information process, and thus enhances suppliers' ability to forecast cash flows. We hypothesize that government suppliers provide higher-quality management forecasts than corporate suppliers.

MEFs constitute an important channel of voluntary disclosure through which managers communicate with market participants and have been the subject of numerous studies in the past decades (see the review by Healy and Palepu 2001; Hirst et al. 2008; Leuz and Wysocki 2016; and the references therein). ${ }^{5}$ Despite extensive research on

\footnotetext{
${ }^{4}$ In the US, the use of accrual accounting by local governments is mandated by the state or is at the discretion of the local governments (Baber and Gore 2008; Gore 2004).

${ }^{5}$ Beyer et al. (2010) show that, between 1994 and 2007, MEFs provided almost 55\% of the accounting-based information that is incorporated into stock price annually. Chen et al. (2011) provide evidence that once a firm starts to issue an earnings forecast, it is costly to cease issuing further MEFs.
} 
MEFs, "forecast characteristics appear to be the least understood component of earnings forecasts-both in terms of theory and empirical research-even though it is the component over which managers have the most control" (Hirst et al. 2008). Our empirical results from univariate and multivariate analyses show that the MEFs issued by government suppliers are of higher quality than those by corporate suppliers. First, we find that government suppliers issue more precise MEFs than corporate suppliers. Second, government suppliers issue more accurate MEFs than corporate suppliers. However, the difference in accuracy between the two groups of suppliers is insignificant when the managers' earnings forecast exceeds or merely matches the analysts' consensus forecast. Third, when managers disclose negative information to the market, MEFs issued by government suppliers have greater price impact than those issued by corporate suppliers. Collectively, the evidence supports our hypothesis that having major government customers is associated with higher-quality supplier MEFs.

Our study contributes to the supply chain literature by identifying customer type as a unique factor in affecting suppliers' voluntary disclosure quality. While investors of corporate suppliers can, in general, enjoy the benefit of information spillover via public information disclosed by customers, we show that government suppliers tend to issue higher-quality MEFs than corporate suppliers. We interpret the results as evidence that having government entities as a major customer can have some positive influence on the quality of information that suppliers provide to the capital market. Prior research on the effects of government spending produces mixed findings. While some studies document an adverse impact of government as a major customer on firms' incentive to invest and compete (Cohen and Malloy 2016), others find a positive effect on suppliers' profitability and loan contract terms (Cohen and Li 2020; Dhaliwal et al. 2016). Our study adds to this line of research by showing a positive impact of major government customers on the quality of supplier MEFs.

In addition, our paper builds on and contributes to the extensive literature on MEFs. By classifying government suppliers versus corporate suppliers and investigating the difference in the characteristics of the MEFs issued by these two groups of firms, our paper answers the call for more research on the characteristics of MEFs (Hirst et al. 2008). Recent work by Shroff et al. (2017) improves our understanding of disclosure externalities by showing that the information environment of peer firms is negatively associated with a firm's cost of equity capital when there is less publicly available firmspecific information. We provide interesting insights that having sales transactions with the U.S. government improves the quality of supplier MEFs.

The remainder of the paper is organized as follows. Section 2 discusses related literature and develops our hypothesis. Section 3 describes the data, samples of observations, and variables. Section 4 presents the empirical results. Section 5 summarizes and concludes.

\section{Hypothesis development}

We investigate whether having a major government customer has any significant impact on the quality of management forecasts. On the demand side, corporate customers may have a greater demand for high-quality voluntary disclosure from suppliers than government customers. Crawford et al. (2020) point out that government customers have lower demand for suppliers' public disclosure because they have greater 
bargaining and enforcement power to obtain information from their suppliers through private communications. However, their empirical analysis focuses only on corporate customers and does not inform us how the impact of government customers may differ from that of corporate customers. In general, corporations do not have the same level of enforcement and bargaining power as government entities and consider public disclosure as a credible information source that is supplementary to private communications. Thus, there is a relatively greater demand for suppliers' public disclosure among corporate customers than among government customers. The demand side analysis suggests that, in order to meet the demand of their major customers, corporate suppliers should provide higher-quality public disclosure than government suppliers.

On the supply side, business transactions with the U.S. government have unique features that improve the quality of government supplier MEFs. First, unlike corporations, government entities are much less likely to default or declare bankruptcy. They tend to offer longer-term procurement contracts and have more enforcement and bargaining power to monitor suppliers closely (Samuels, in press). When uncertainty about future customer demand is low, suppliers are able to plan and undertake customer-specific investments more efficiently (Chiu et al. 2019; Guiso and Parigi 1999). Cohen and Li (2020) find that suppliers with major government customers achieve greater efficiency in asset turnover and customer-specific SG\&A investments, which leads to lower operational uncertainty and higher profitability. Second, government entities have objectives that differ from those of corporations and their decisions are often affected by nonprofit considerations, such as social welfare, environmental awareness, political lobbying, and campaign donations (Goldman et al. 2013). Firms contracting with government entities tend to face less competition in the product market and generate a large portion of their revenues from non-competitive procurement contracts (Mills et al. 2013). Li (2010) and Huang et al. (2017) find that product market competition affects corporate voluntary disclosure. ${ }^{6}$ Third, government agencies follow a standard procurement process regulated by FARs and require comprehensive information to assess whether the supplier has adequate financial resources to deliver the goods and services as expected. In order to meet the information demand from government procurement, government suppliers are likely to have a more efficient internal information process (Samuels, in press).

Suppliers choose the level of forecast quality by balancing between their major customers' demand and their ability to forecast future cash flows. Given that managers face litigation and reputational considerations (Skinner 1994, 1997), while they strive to meet major customers' demand for public guidance, their ability to forecast future earnings is the binding determinant of the quality of their forecasts. Thus, we hypothesize that government suppliers provide higherquality management guidance than corporate suppliers. Specifically, our hypothesis states:

\footnotetext{
${ }^{6}$ Their results support the notion that proprietary costs are an important factor that firms consider in making voluntary disclosure decisions (Verrecchia 1983). Huang et al. (2017) study the effect of product market competition on forecast frequency and show that when facing tougher competition in the product market, firms are less likely to issue management forecasts. Samuels (in press) finds that having major government customers increases the frequency of supplier management forecasts. Our research complements the study by focusing on the suppliers that issue management forecasts and by examining the differences in the quality of government supplier and corporate supplier management forecasts.
} 
Hypothesis: management forecasts of government suppliers are more precise, more accurate, and have a greater price impact than those of corporate suppliers

Our theoretical analysis above focuses on how the type of a firm's customer affects both the customers' demand for management guidance and the suppliers' ability to forecast future earnings. It is plausible that the quality of MEFs is affected by other factors. For example, outside investors also demand that suppliers provide voluntary public disclosure. However, major customers are likely to have greater impact on the quality of supplier management forecasts than outside investors, given that the customer-supplier relationship has a significant influence on major corporate decisions, such as accounting policies (Hui et al. 2012; Raman and Shahrur 2008), tax avoidance strategies (Cen et al. 2017), and so on. Hence, we expect our hypothesis continues to be valid after considering outside investors' demand. In our empirical analysis, we include control variables that are likely to affect the quality of MEFs.

Our study adds to the existing literature by showing that the MEFs of supplier firms with different customer base compositions, i.e., having government entities versus public listed firms as major customers, exhibit different characteristics. We study three characteristics of MEFs, namely forecast precision, forecast accuracy, and price impact, because they are commonly studied in the MEF literature and managers have different degrees of control over them. First, forecast precision is under managers' direct control at the time when the forecast is determined. Second, forecast accuracy depends on the actual earnings that are released after the forecast. Though managers have superior knowledge to outsiders, they still face uncertainty about the exact amount that the actual earnings will be. Third, price impact depends on investors' inference of new information in management forecasts and market conditions. We expect that the difference between the MEFs of government suppliers and corporate suppliers is greater in the forecast characteristic over which managers have a stronger control.

\section{Data and variable}

We collect customer-supplier relationship data from the Compustat Segment database. The Financial Accounting Standards Board's new segment reporting standard was issued in June 1997 and became effective for financial reporting periods beginning after December 15, 1997 (Berger and Hann 2003). Hence, our sample period starts from the fiscal year ending in 1998.

The Compustat Segment database classifies each customer into seven categories: "GOVDOM," "GOVSTATE," "GOVLOC," "COMPANY," "GEOREG," "MARKET," and "GOVFRN." We classify a supplier as a corporate supplier if the firm reports only sales to major customers in the "COMPANY" category in three consecutive years. We classify a supplier as a government supplier if the firm reports only sales to major customers in the "GOVDOM," "GOVSTATE," and "GOVLOC" categories in three consecutive years. ${ }^{7}$ Thus, our sample includes only suppliers that do not switch from

\footnotetext{
${ }^{7}$ Major customers in the "GOVDOM," "GOVSTATE," and "GOVLOC" categories are government entities at the federal, state, and municipal level in the US. Major customers in the "GOVFRN" category are government entities outside the US, for example, the governments of Abu Dhabi, Australia, Canada, China, Israel, Peru, and so on. Only about $1 \%$ of data records in the Compustat Segment database are associated with the "GOVFRN" category.
} 
one type to another. For example, if a supplier reports any sales to a non-government customer in any given year, it drops out of our sample of government suppliers in that year and onward. The three-year restriction ensures that the customer type of a supplier is stable over an extended period, and thus our empirical analysis is not contaminated by suppliers switching from one type to another.

We obtain management forecasts of quarterly earnings from the IBES Earnings Guidance database. For a government supplier whose major customers are exclusively government entities in three consecutive fiscal years, $t-2, t-1$, and $t$, we collect the management forecasts for quarterly earnings that the supplier released within the fiscal years $t$ and $t+1$. For a corporate supplier whose major customers are exclusively public companies in three consecutive fiscal years, $t-2, t-1$, and $t$, we collect the management forecasts for quarterly earnings that the supplier released within the fiscal years $t$ and $t+1$. If a supplier issues multiple forecasts of the same quarter's earnings, we keep the last forecast before the earnings announcement.

For each MEF, we calculate the precision, accuracy, and price impact. We follow prior studies to measure forecast precision as the negative of the difference between the upper end and the lower end of a range forecast, scaled by the beginning-of-quarter stock price, or 0 for a point forecast. We measure forecast accuracy by the absolute forecast error, that is, the absolute value of the difference between actual earnings and the forecast value, scaled by the beginning-of-quarter stock price. For a range forecast, the forecast value is equal to its midpoint. We measure the price impact by the marketadjusted cumulative abnormal returns in the four-day $[-2,1]$ window around the forecast release day (i.e., day 0 ).

In addition, we measure the information content in a management forecast by the difference between the forecast value and the median of analysts' earnings forecasts as of the day prior to the release of the management forecast. We also measure several firm characteristics, such as firm size (SIZE), book-to-market ratio $(B M R)$, return on assets $(R O A)$, stock return volatility (RETVOL), a loss dummy variable (LOSS), annual sales growth (GROWTH), debt-asset ratio (LEV), and firm age (AGE). SIZE is equal to the logarithm of the market capitalization at the beginning of the current quarter. $B M R$ is the book-to-market-equity ratio at the beginning of the current quarter. $R O A$ is the return on assets for the previous fiscal year. RETVOL is equal to the standard deviation of daily stock returns in the past 12 months before the current quarter. LOSS is a dummy variable that equals 1 if the quarterly earnings is negative and 0 otherwise. GROWTH is the logarithm of the ratio of the annual sales in the immediate past two consecutive fiscal years. $L E V$ is the total debt divided by the total assets in the immediate past fiscal year. $A G E$ is the logarithm of 1 plus the number of years between the firm's start date in the CRSP database and the end of the quarter for which management issued an earnings forecast. All continuous variables are winsorized at the $1 \%$ and 99\% percentiles of the whole sample.

We obtain financial statement data from the Compustat, stock prices and returns from the CRSP, and analyst forecasts from the IBES Detailed Analyst Forecast database. Our sample includes management forecasts that have non-missing values for all of the above variables. The final sample includes 764 MEFs issued by 133 corporate suppliers and 404 MEFs issued by 75 government suppliers. According to the 48 industry classifications in Fama and French (1997), the 75 government suppliers belong to 20 
Table 1 Descriptive statistics

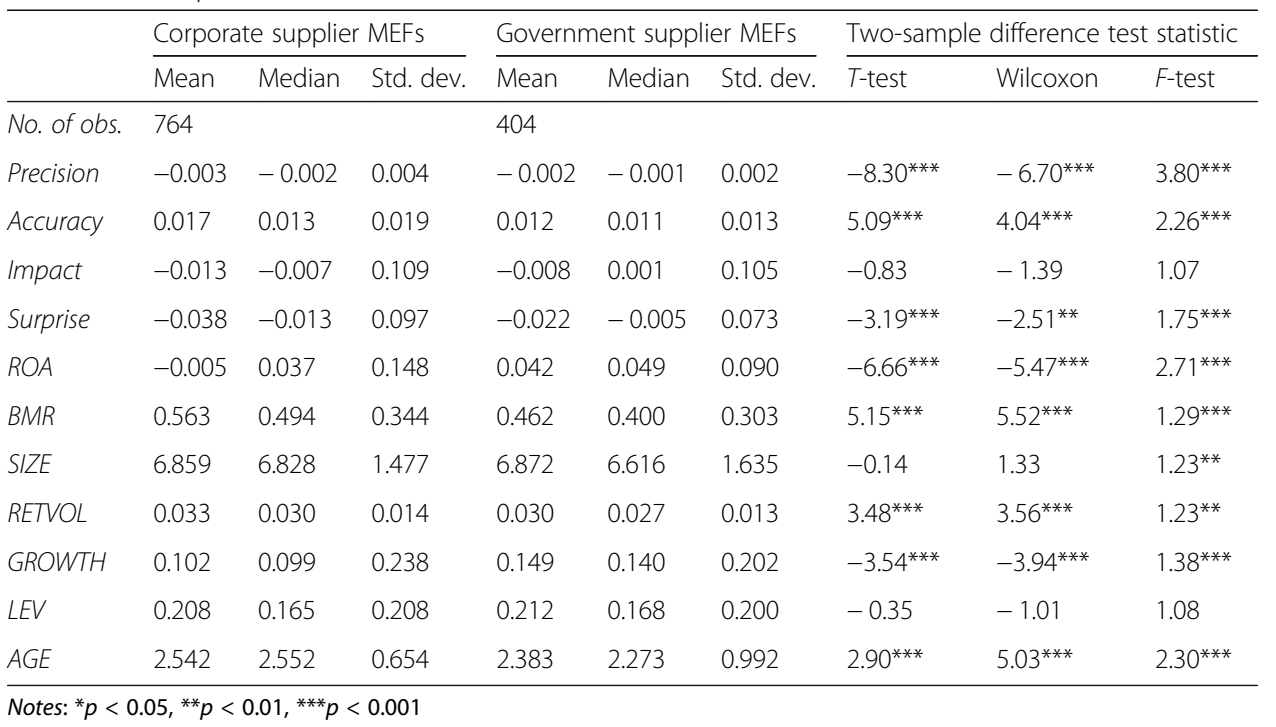

industries, while the 133 corporate suppliers are from 26 industries. The Business Services industry has the largest number of government suppliers, whereas the Electronic Equipment industry has the largest number of corporate suppliers.

\section{Empirical results}

\section{Univariate comparison between corporate and government suppliers}

By examining the differences in the characteristics of management forecasts between corporate suppliers and government suppliers, we expect to find empirical evidence for or against our hypothesis. In this section, we compare the two groups of suppliers with regard to three forecast characteristics, namely, forecast precision, forecast accuracy, and price impact. As discussed earlier, managers have different levels of control over the three characteristics, with the strongest control being over forecast precision, followed by forecast accuracy, and then price impact.

Table 1 reports the mean, median, and standard deviation of the three forecast characteristics for corporate suppliers and government suppliers, separately. We observe several significant differences in the forecast properties and firm characteristics between the two groups. The first set of differences exist in the forecast properties. Specifically, government suppliers issue more precise forecasts than corporate suppliers. The mean (median) forecast precision of government supplier MEFs is $-0.002(-0.001)$, whereas the mean (median) forecast precision of corporate supplier MEFs is only -0.003 (0.002). Statistical tests show that both the mean and median are significantly different between the two groups of suppliers. ${ }^{8}$ The evidence is consistent with the hypothesis, which predicts that government suppliers have less operational uncertainty and hence managers are able to provide more precise forecasts.

\footnotetext{
${ }^{8}$ The $F$-test shows that the two groups have significantly different standard deviations in forecast precision. We use the $t$-statistic with the Satterthwaite adjustment for unequal variance to test whether the two groups have the same mean. We use the Wilcoxon statistics with normal approximation to test whether the two groups have the same median.
} 
Moreover, government suppliers issue more accurate forecasts than corporate suppliers. The mean (median) forecast accuracy of government supplier MEFs is 0.012 (0.011), whereas the mean (median) forecast accuracy of corporate supplier MEFs is 0.017 (0.013). Both mean and median are significantly different between the two groups of suppliers. Again, the evidence supports our hypothesis. However, the difference in forecast accuracy between the two groups is much smaller than the difference in forecast precision. This is consistent with the notion that managers have stronger control in determining forecast precision than forecast accuracy.

Finally, there is no significant difference in the price impact of management forecasts between corporate suppliers and government suppliers. The mean (median) cumulative abnormal return is $-0.8 \%(0.1 \%)$ in the four-day window around the release of government supplier MEFs, whereas the mean (median) cumulative abnormal return is $-1.3 \%(-0.7 \%)$ around the release of corporate supplier MEFs. The abnormal returns have a very large standard deviation, $10.5 \%$ for government suppliers and $10.9 \%$ for corporate suppliers.

The second difference between the two groups exists in the information content of the MEFs, measured by the difference between the forecast value and the median analysts' forecast, which we call the MEF surprise. The mean (median) surprise in corporate supplier MEFs is $-0.038(-0.013)$, whereas the mean (median) surprise in government supplier MEFs is $-0.022(-0.005)$. The average surprise being negative is consistent with the well-documented phenomenon that managers tend to issue warnings if their earnings fall below expectations (Kasznik and Lev 1995). Relative to corporate suppliers, government suppliers have a statistically significant smaller shortfall from forecasted earnings, which is consistent with a lower level of operational uncertainty in government suppliers.

The third set of differences lies in firm characteristics, such as firm size, profitability, book-to-market ratio, and return volatility. Government suppliers are more profitable than corporate suppliers. The mean $R O A$ is $-0.5 \%$ for corporate suppliers but is positive at $4.2 \%$ for government suppliers. Corporate suppliers have a much larger standard deviation in profitability than government suppliers, with median $R O A s$ of $3.7 \%$ and $4.9 \%$, respectively. Both the $B M R$ and RETVOL are significantly higher for corporate suppliers than for government suppliers. The mean daily RETVOL is $3.3 \%$ for corporate suppliers, but $3.0 \%$ for government suppliers. However, there is no significant difference in firm size between the two groups of suppliers. The average market capitalization of both groups of suppliers is about USD 950 million.

We also examine the correlation coefficients of these variables for the whole sample and observe several patterns. First, forecast precision and forecast accuracy have a large negative correlation coefficient of -0.491 , which suggests that more precise forecasts tend to have a higher level of accuracy. Second, forecast precision has relatively large positive correlation with $R O A$ and SIZE but large negative correlation with $B M R$ and RETVOL. The evidence suggests that larger and more profitable suppliers issue more precise forecasts, while suppliers with a higher book-to-market ratio and higher return volatility have less precise forecasts. Third, forecast accuracy has relatively large negative correlation with $R O A$ and SIZE but large positive correlation with $B M R$ and RETVOL. The evidence suggests that larger and more profitable suppliers have more accurate forecasts, while suppliers with a higher book-to-market ratio and higher return volatility issue less accurate forecasts. Moreover, there is a large positive correlation 
between price impact and MEF surprise. A management forecast of a large surprise causes price to move in the same direction by a large amount.

The IBES Earnings Guidance database provides a classification code to indicate the information content in a management forecast. The code takes one of the four values, 12 , 3, and 6, with 1 for the MEF missing the analyst consensus forecast, 2 for the MEF beating the analyst consensus forecast, 3 for the MEF matching the analyst consensus forecast, and 6 for unclassified MEFs. It is unclear how well the IBES code captures the information content of an MEF.

We measure the information content by the MEF surprise, which is equal to the difference between the forecast value and the median of analyst forecasts as of the day prior to the MEF release day. We group MEFs into three subsamples according to the MEF surprise: the MEFs with a surprise less than or equal to -0.01 , the MEFs with a surprise greater than -0.01 and less than 0.01 , and the MEFs with a surprise greater than or equal to 0.01 . We call them the negative surprise subsample, the match (no surprise) subsample, and the positive surprise subsample.

The MEFs are grouped into the three subsamples for two reasons. First, all the MEFs in the match subsample have a surprise close to 0 . Firms may have provided such forecasts because it is their routine practice. It is reasonable to expect that the difference in the MEF quality between government suppliers and corporate suppliers is small in the match subsample.

Second, financial reporting follows the accounting conservatism principle that requires a high degree of verification before firms can make a legal claim to any profit. As a result, unrealized losses are typically recognized earlier than unrealized gains (Basu 1997). In addition, managers may be sued or incur reputational costs if stockholders suffer from a large stock price decline because of a negative earnings surprise. Thus managers tend to disclose bad news in a timely manner (Skinner 1994). Consistent with this view, we find a larger number of negative-surprise MEFs (588) than the number of positive-surprise MEFs (295) in our sample. Because managers exercise more caution in issuing negative-surprise MEFs, we expect that the influence of major government customers on the MEF quality is stronger in the negative surprise subsample than in the positive surprise subsample.

We now examine the number of MEFs that are classified in subsamples according to both the IBES code and the MEF surprise. While IBES code 1 is highly consistent in capturing MEFs that miss the analyst consensus forecast, IBES codes 3 and 6 do a poor job in capturing the information content in management forecasts. Specifically, out of the 160 MEFs that have an IBES code equal to 6, we find that 64 have negative MEF surprise, 51 match the median analyst forecast, and 45 have positive MEF surprise. Similarly, out of the 445 MEFs with IBES code 3, 121 have negative surprise, 101 have positive surprise, and only 223 match the median analyst forecast. The number of MEFs with negative surprise doubles that of MEFs with positive surprise. Based on the above observation, we believe that compared to the IBES code classification, our classification of the MEF surprise provides a finer and more accurate proxy for the information content of a management forecast.

We can gain further insight by examining the mean and median surprises of MEFs in each subsample. For the 1168 MEFs, the mean (median) surprise is -0.034 $(-0.010)$. For the 588 MEFs with negative surprise, the mean (median) surprise is -0.094 (-0.055). For the 295 MEFs with positive surprise, the mean (median) 
surprise is $0.052(0.030)$. For the $285 \mathrm{MEFs}$ that match the consensus analyst forecast, the mean (median) surprise is $0.0002(0)$.

Taken together, the subsample descriptive statistics reveal that the MEF surprise does a better job than the IBES code of separating MEFs into groups according to the information content. In the following analysis, we study the three subsamples grouped by MEF surprise. Within each subsample, we compare corporate supplier MEFs with government supplier MEFs.

We first examine the differences in three MEF characteristics between corporate suppliers and government suppliers for the subsample of negative MEF surprise. The two groups of suppliers have similar firm characteristics. They are only marginally different in the median of profitability, book-to-market ratio, and daily return volatility. The average firm size of corporate suppliers is USD961 million, while the average firm size of government suppliers is USD706 million. Turning to forecast properties, government suppliers have significantly more precise and more accurate forecasts than corporate suppliers. The magnitude of negative surprise is much greater for corporate suppliers than for government suppliers. The mean (median) surprise of corporate suppliers' forecasts is $-0.096(-0.065)$, whereas the mean (median) surprise of government suppliers' forecasts is $-0.071(-0.043)$. However, there is no significant difference in the price impact between the two groups of suppliers.

Next, we check the differences between corporate suppliers and government suppliers for the subsample of MEFs that match the median analysts forecast. The two groups of suppliers appear to differ in several aspects. Government suppliers are more profitable, and have a smaller book-to-market ratio, larger firm size and lower stock return volatility than corporate suppliers. Again, they have significantly more precise forecasts than corporate suppliers. However, there is no significant difference in forecast accuracy between the two groups. Both corporate suppliers and government suppliers have, on average, positive abnormal return in the four-day window. Government suppliers have marginally larger price impact than corporate suppliers, despite the fact that there is no significant difference in the MEF surprise between the two groups.

At last, we compare corporate suppliers with government suppliers for the subsample of positive news MEFs. Government suppliers are significantly more profitable and have a significantly smaller book-to-market ratio than corporate suppliers. The two groups are similar in firm size and stock return volatility. Government suppliers have significantly more precise and more accurate forecasts than corporate suppliers. However, there is no significant difference in the price impact, nor in the MEF surprise, between the two groups.

In summary, the above univariate comparison shows that government suppliers issue more precise and more accurate management forecasts than corporate suppliers. The difference in the price impact between the two groups of suppliers varies across the subsamples of MEFs.

\section{Regression analysis of forecast characteristics}

In the following analysis, we test our hypothesis in a regression framework that controls for the differences in firm characteristics among suppliers. In view of the differences between the subsamples of MEFs, we carry out the regression analysis for the whole 
sample of MEFs, as well as the three subsamples separately. First, we estimate the following regression model of forecast precision

$$
\text { Precision }=\alpha+\beta G O V+\theta X+\varepsilon,
$$

where the dependent variable, Precision, is the forecast precision, the independent variable $G O V$ is the government indicator that equals 1 if the forecast is issued by a government supplier, and $X$ represents the vector of control variables that includes SIZE, BMR, ROA, RETVOL, LOSS, GROWTH, LEV, and AGE. Table 2 reports the results of estimating the regression model in Eq. (1). We estimate the regression model with clustered errors across customers and report the results in the column "Model 1" in Table 2. In addition, we include the industry fixed effects and the year fixed effects in the regression model and report the estimation results in the column "Model 2." All coefficients in Table 2 are multiplied by a factor of 1000 .

For the whole sample, the coefficient of the variable $G O V$ is positive and significant at the $5 \%$ level, even after we include the fixed year and industry effects in the regression. In addition, the coefficient of the variable GOV is positive and statistically significant in both the positive surprise subsample and the negative surprise subsample. The

Table 2 Regressions of forecast precision

\begin{tabular}{|c|c|c|c|c|c|}
\hline & \multicolumn{2}{|c|}{ Whole sample } & \multicolumn{3}{|l|}{ Subsamples } \\
\hline & Model 1 & Model 2 & Negative surprise & Match & Positive surprise \\
\hline \multirow[t]{2}{*}{ Intercept } & $-3.135^{* *}$ & $-3.148^{* *}$ & $-2.741^{*}$ & $-2.969^{*}$ & -3.500 \\
\hline & $(-2.35)$ & $(-2.07)$ & $(-1.76)$ & $(-1.85)$ & $(-1.47)$ \\
\hline \multirow[t]{2}{*}{ GOV } & $1.024^{* *}$ & $0.749^{* *}$ & $0.987^{*}$ & 0.358 & $1.320^{* * *}$ \\
\hline & $(2.28)$ & $(2.07)$ & $(1.76)$ & $(0.83)$ & (2.92) \\
\hline \multirow[t]{2}{*}{ BMR } & -0.956 & -0.659 & $-1.783^{* *}$ & 0.373 & -0.477 \\
\hline & $(-1.24)$ & $(-0.85)$ & $(-1.96)$ & $(0.32)$ & $(-0.38)$ \\
\hline \multirow[t]{2}{*}{$R O A$} & 2.191 & 1.251 & 1.981 & 3.797 & 1.359 \\
\hline & $(1.10)$ & $(0.63)$ & $(0.93)$ & $(1.26)$ & $(0.44)$ \\
\hline \multirow[t]{2}{*}{ SIZE } & $0.394^{* *}$ & $0.342^{* *}$ & 0.271 & $0.400^{* *}$ & $0.535^{*}$ \\
\hline & $(2.24)$ & $(2.00)$ & $(1.51)$ & $(2.04)$ & $(1.78)$ \\
\hline \multirow[t]{2}{*}{ RETVOL } & $-25.134^{*}$ & -14.157 & -8.945 & -29.190 & $-43.408^{*}$ \\
\hline & $(-1.92)$ & $(-0.84)$ & $(-0.62)$ & $(-1.34)$ & $(-1.94)$ \\
\hline \multirow[t]{2}{*}{ LOSS } & $-1.354^{* * *}$ & $-1.358^{* * *}$ & $-1.506^{* * *}$ & $-1.377^{*}$ & $-1.585^{*}$ \\
\hline & $(-3.27)$ & $(-3.26)$ & $(-3.40)$ & $(-1.79)$ & $(-1.85)$ \\
\hline \multirow[t]{2}{*}{ GROWTH } & 1.091 & $1.635^{* *}$ & 0.773 & 0.524 & 1.780 \\
\hline & $(1.59)$ & $(2.41)$ & $(0.89)$ & $(0.66)$ & $(1.26)$ \\
\hline \multirow[t]{2}{*}{ LEV } & $-3.342^{*}$ & $-3.386^{*}$ & -3.572 & -0.514 & $-4.607^{* *}$ \\
\hline & $(-1.66)$ & $(-1.90)$ & $(-1.55)$ & $(-0.35)$ & $(-2.05)$ \\
\hline \multirow[t]{2}{*}{ AGE } & -0.093 & 0.058 & 0.093 & -0.307 & -0.256 \\
\hline & $(-0.43)$ & $(0.24)$ & $(0.35)$ & $(-1.15)$ & $(-0.78)$ \\
\hline Industry FE & No & Yes & No & No & No \\
\hline Year FE & No & Yes & No & No & No \\
\hline Clustered error & Yes & Yes & Yes & Yes & Yes \\
\hline No. of obs. & 1,149 & 1,149 & 578 & 282 & 289 \\
\hline Adj. $R^{2}$ & 0.204 & 0.247 & 0.177 & 0.190 & 0.259 \\
\hline
\end{tabular}

Notes: ${ }^{*} p<0.05,{ }^{* *} p<0.01,{ }^{* * *} p<0.001$ 
evidence supports our hypothesis that government suppliers issue more precise forecasts than corporate suppliers.

Turning to control variables, both $R O A$ and SIZE have significantly positive coefficients in the three subsamples, suggesting that profitable and large suppliers tend to have higher forecast precision. Although the coefficients of $B M R$ and RETVOL have the negative sign in the three subsamples, the coefficient of $B M R$ is statistically significant only in the negative surprise subsample, while the coefficient of RETVOL is statistically significant only in the positive surprise subsample.

Next, we estimate the following regression model of forecast accuracy

$$
\text { Accuracy }=\alpha+\beta G O V+\theta X+\varepsilon,
$$

where the dependent variable, Accuracy, is the forecast accuracy. Table 3 reports the results of estimating the regression model in Eq. (2) for the whole sample of MEFs, as well as the three subsamples separately. We estimate the regression model with clustered errors across customers and report the results in the column "Model 1" in Table 3. In addition, we include the industry fixed effects and the year fixed effects in the

Table 3 Regressions of forecast accuracy

\begin{tabular}{|c|c|c|c|c|c|}
\hline & \multicolumn{2}{|c|}{ Whole sample } & \multicolumn{3}{|l|}{ Subsamples } \\
\hline & Model 1 & Model 2 & Negative surprise & Match & Positive surprise \\
\hline \multirow[t]{2}{*}{ Intercept } & $17.119^{* * *}$ & $17.593^{* * *}$ & $17.381^{* *}$ & 7.173 & $23.032^{* * *}$ \\
\hline & $(2.97)$ & $(2.82)$ & $(2.49)$ & $(0.99)$ & (2.68) \\
\hline \multirow[t]{2}{*}{ GOV } & $-2.789^{*}$ & -2.051 & $-3.676^{* *}$ & -0.982 & -2.257 \\
\hline & $(-1.84)$ & $(-1.49)$ & $(-2.13)$ & $(-0.57)$ & $(-0.92)$ \\
\hline \multirow[t]{2}{*}{$B M R$} & $11.070^{* * *}$ & $9.539^{* * *}$ & $10.223^{* *}$ & $14.931^{* *}$ & $10.754^{* *}$ \\
\hline & (3.73) & $(3.32)$ & $(2.48)$ & $(2.37)$ & $(2.40)$ \\
\hline \multirow[t]{2}{*}{$R O A$} & -16.721 & -15.311 & $-26.710^{* *}$ & 7.079 & -13.402 \\
\hline & $(-1.58)$ & $(-1.52)$ & $(-1.96)$ & $(0.59)$ & $(-1.03)$ \\
\hline \multirow[t]{2}{*}{ SIZE } & $-1.154^{*}$ & -0.990 & -0.750 & -0.848 & $-2.190^{* * *}$ \\
\hline & $(-1.91)$ & $(-1.61)$ & $(-0.98)$ & $(-1.15)$ & $(-2.63)$ \\
\hline \multirow[t]{2}{*}{ RETVOL } & 12.591 & 11.550 & -63.208 & 61.684 & 70.626 \\
\hline & $(0.18)$ & $(0.15)$ & $(-0.83)$ & $(0.82)$ & $(0.65)$ \\
\hline \multirow[t]{2}{*}{ LOSS } & 2.693 & $2.991^{*}$ & $4.175^{* *}$ & -0.029 & 6.777 \\
\hline & $(1.60)$ & $(1.78)$ & (2.08) & $(-0.01)$ & $(1.42)$ \\
\hline \multirow[t]{2}{*}{ GROWTH } & 0.668 & -1.908 & 0.757 & 1.285 & 2.120 \\
\hline & $(0.22)$ & $(-0.65)$ & $(0.26)$ & $(0.38)$ & $(0.35)$ \\
\hline \multirow[t]{2}{*}{ LEV } & 6.572 & 5.893 & 7.311 & 3.454 & 7.660 \\
\hline & $(1.16)$ & $(1.11)$ & (1.19) & $(0.57)$ & $(1.15)$ \\
\hline \multirow[t]{2}{*}{$A G E$} & -0.425 & -1.080 & -0.815 & 0.546 & 0.298 \\
\hline & $(-0.50)$ & $(-1.34)$ & $(-0.92)$ & $(0.56)$ & $(0.21)$ \\
\hline Industry FE & No & Yes & No & No & No \\
\hline Year FE & No & Yes & No & No & No \\
\hline Clustered error & Yes & Yes & Yes & Yes & Yes \\
\hline No. of obs. & 1,149 & 1,149 & 578 & 282 & 289 \\
\hline Adj. $R^{2}$ & 0.145 & 0.174 & 0.138 & 0.155 & 0.182 \\
\hline
\end{tabular}

Notes: ${ }^{*} p<0.05,{ }^{* *} p<0.01,{ }^{* * *} p<0.001$ 
regression model and report the estimation results in the column "Model 2." All coefficients in Table 3 are multiplied by 1,000.

For the whole sample, the coefficient of the variable $G O V$ is negative and significant at the $10 \%$ level; however, it is insignificant when the year and industry fixed effects are included in the regression. The coefficient of the variable GOV is negative in all of the three subsamples but statistically significant only in the negative surprise subsample. Turning to control variables, $B M R$ has significantly positive coefficients in the three subsamples, suggesting that suppliers with higher book-to-market ratios tend to have lower forecast accuracy. The coefficient of $R O A$ is negative and statistically significant only in the negative surprise subsample. SIZE is significant in the positive surprise subsamples, while LOSS is significant in the negative surprise subsample. The results in Table 3 suggest that when they convey negative information to the public, government suppliers issue more accurate forecasts than corporate suppliers.

Finally, we estimate the following regression of the price impact

$$
\text { Impact }=\alpha+\beta \text { Surprise }+\gamma \text { GOV }+\eta \text { GOV } \times \text { Surprise }+\theta X+\varepsilon,
$$

where the dependent variable, Impact, is the price impact, and the variable Surprise is the MEF surprise that proxies for the information content in a management forecast. We include the interaction term, GOV $\times$ Surprise, in the regression of the price impact because the preliminary results in Section 4.1 suggest that the price impact is related to the information content in MEFs. Moreover, we use the interaction term to test whether the price response to new information in MEFs differs between government suppliers and corporate suppliers. The vector of control variables $X$ includes SIZE, $B M R, R O A, R E T V O L, L O S S$, GROWTH, LEV, and AGE. Table 4 reports the results of estimating the regression model in Eq. (3) for the whole sample of MEFs, as well as the three subsamples separately. We estimate the regression model with clustered errors across customers and report the results in the column "Model 1" in Table 4. In addition, we include the industry fixed effects and the year fixed effects in the regression model and report the estimation results in the column "Model 2."

The regression results for the whole sample show that the interaction term GOVxSurprise has a positive and significant coefficient, which holds with the fixed year and industry effects in the regression and the firm-clustered error estimation. This suggests that government suppliers experience a larger price response to their management forecasts than corporate suppliers.

The regression results differ across the three subsamples. In the regression for the positive surprise subsample, the coefficient of $G O V$ is positive but insignificant. In the regression for the match subsample, the coefficient of GOV is negative and significant at the $10 \%$ level. In the regression for the negative surprise subsample, the adjusted $R$ squared is 0.084 , and the regression is more informative. The coefficient of the variable Surprise is positive and significant. Since Surprise is negative for all observations in this sample, a positive coefficient means that a more negative surprise causes a larger stock price drop. In addition, the interaction $G O V \times$ Surprise has a positive and significant coefficient. This suggests that government suppliers experience a larger stock price drop than corporate suppliers when their MEFs fall short of the analyst consensus forecast. The results in Table 4 are consistent with our hypothesis that MEFs issued by government suppliers have a greater price impact. 
Table 4 Regressions of price impact

\begin{tabular}{|c|c|c|c|c|c|}
\hline & Whole sam & & Subsamples & & \\
\hline & Model 1 & Model 2 & Negative surprise & Match & Positive surprise \\
\hline Intercept & 0.012 & $0.052^{*}$ & -0.041 & 0.038 & $0.065^{*}$ \\
\hline & $(0.50)$ & $(1.92)$ & $(-1.24)$ & $(1.15)$ & $(1.65)$ \\
\hline GOV & 0.007 & 0.009 & 0.001 & $0.020^{*}$ & -0.009 \\
\hline & $(0.95)$ & (1.39) & $(0.06)$ & $(1.76)$ & $(-0.58)$ \\
\hline Surprise & $0.366^{* * *}$ & $0.376^{* * *}$ & $0.198^{* * *}$ & 1.130 & 0.044 \\
\hline & $(6.46)$ & $(7.00)$ & $(3.76)$ & $(0.92)$ & $(0.30)$ \\
\hline GOV×Surprise & $0.303^{* *}$ & $0.290^{* *}$ & $0.235^{*}$ & 0.616 & 0.324 \\
\hline & $(2.44)$ & $(2.41)$ & $(1.82)$ & $(0.32)$ & $(1.32)$ \\
\hline$B M R$ & $0.033^{* * *}$ & $0.023^{* *}$ & $0.054^{* * *}$ & 0.005 & 0.021 \\
\hline & $(2.99)$ & $(2.06)$ & (3.93) & $(0.24)$ & (1.16) \\
\hline$R O A$ & -0.050 & $-0.063^{*}$ & $-0.089^{*}$ & $0.093^{* *}$ & -0.074 \\
\hline & $(-1.39)$ & $(-1.75)$ & $(-1.88)$ & $(2.09)$ & $(-1.25)$ \\
\hline SIZE & -0.000 & -0.000 & 0.004 & $-0.007^{* *}$ & -0.005 \\
\hline & $(-0.06)$ & $(-0.05)$ & $(1.29)$ & $(-2.18)$ & $(-1.22)$ \\
\hline RETVOL & $-0.538^{*}$ & $-0.872^{* * *}$ & $-1.540^{* * *}$ & 0.029 & 0.388 \\
\hline & $(-1.95)$ & $(-2.66)$ & $(-4.27)$ & $(0.06)$ & $(0.85)$ \\
\hline LOSS & $-0.035^{* * *}$ & $-0.031^{* * *}$ & $-0.020^{*}$ & $-0.024^{* *}$ & $-0.050^{* * *}$ \\
\hline & $(-4.08)$ & $(-3.71)$ & $(-1.84)$ & $(-1.99)$ & $(-2.82)$ \\
\hline GROWTH & -0.014 & $-0.023^{*}$ & -0.023 & $-0.044^{*}$ & 0.042 \\
\hline & $(-1.10)$ & $(-1.84)$ & $(-0.99)$ & $(-1.93)$ & (1.59) \\
\hline LEV & 0.020 & 0.009 & $0.049^{* *}$ & 0.019 & $-0.037^{*}$ \\
\hline & $(1.28)$ & $(0.64)$ & $(2.08)$ & $(0.72)$ & $(-1.69)$ \\
\hline AGE & -0.002 & -0.005 & -0.001 & 0.005 & 0.002 \\
\hline & $(-0.30)$ & $(-0.96)$ & $(-0.09)$ & $(0.72)$ & $(0.36)$ \\
\hline Industry FE & $\mathrm{No}$ & Yes & No & No & No \\
\hline Year FE & No & Yes & No & No & No \\
\hline Clustered error & Yes & Yes & Yes & Yes & Yes \\
\hline No. of obs. & 1149 & 1149 & 578 & 282 & 289 \\
\hline Adj. $R^{2}$ & 0.051 & 0.067 & 0.084 & 0.031 & 0.036 \\
\hline
\end{tabular}

Notes: ${ }^{*} p<0.05,{ }^{* *} p<0.01,{ }^{* * *} p<0.001$

\section{Channels of government influence and endogeneity issues}

In this section, we report additional results from an attempt to identify the channel through which major government customers influence the quality of their supplier MEFs. Due to a lack of access to corporate internal data that is required for a careful analysis of the internal information process channel, we focus our analysis on the demand uncertainty channel and the product market competition channel. We calculate the proxy variables for the level of demand uncertainty and the level of product market competition for the suppliers that issued the MEFs in our sample. Specifically, for each MEF in our sample, we follow Cohen and Li (2020) to calculate the proxy for the level of demand uncertainty $(D U)$ as the standard deviation of sales growth of the issuing firm in the five-year $[-2,2]$ period around the current fiscal year (i.e., year 0 ). We follow $\mathrm{Li}$ (2010) and others to calculate the proxy for the level of product market 
competition $(P M C)$ as the sum of squared market shares of all firms in an industry in the current fiscal year. Firms are classified into 48 industries according to the classification scheme in Fama and French (1997) and each firm's market share is equal to its sales divided by the total sales of all firms in the same industry.

We examine the mean, median, and standard deviation of the two proxy variables, $D U$ and $P M C$, and test the significance of the differences between corporate supplier MEFs and government supplier MEFs. The mean and the median levels of demand uncertainty are 0.215 and 0.171 , respectively, for the MEFs of corporate suppliers, while they are 0.162 and 0.113 , respectively, for the MEFs of government suppliers. The twosample difference tests show that the differences in both mean and median between these two groups of MEFs are statistically significant. This suggests that government suppliers tend to have lower demand uncertainty than corporate suppliers. As for the level of product market competition, the mean and the median are 0.063 and 0.045 , respectively, for the MEFs of corporate suppliers, while they are 0.072 and 0.052, respectively, for the MEFs of government suppliers. The variable $P M C$ is a measure of the concentration of sales in a particular industry that takes a value between 0 and 1 . A larger value of the variable $P M C$ indicates less competition in the industry. The mean and the median of $P M C$ are relatively low, suggesting that the suppliers that issued the MEFs in our sample operate in highly competitive industries. The difference in both mean and median between corporate suppliers and government suppliers is statistically significant, suggesting that government suppliers face relatively less industry competition than corporate suppliers.

We include the two variables, $D U$ and $P M C$, together with other control variables in the regression models of forecast precision, forecast accuracy, and price impact in Eqs. (1), (2), and (3), respectively. We estimate the regression models with clustered errors across customers. In addition, we include the industry fixed effects and the year fixed effects in the regression models.

The estimation results show that the coefficients of $D U$ and $P M C$ are not statistically significant in all the regression models. There is no evidence that the proxies for demand uncertainty and product market competition are significantly related to the quality of MEFs. Hence, we cannot conclude whether demand uncertainty or industry competition is the channel through which major government customers affect MEF quality.

By comparing the estimation results with those in Tables 2, 3, and 4, we find that the addition of the two control variables, $D U$ and $P M C$, does not change the magnitude and significance level of the coefficients of the other variables in the regression models. The results continue to support our hypothesis that MEFs of government suppliers are more precise and more accurate and have a greater price impact. One reason why the proxy for demand uncertainty and product market competition is not significant on its own is that government influence through two or more channels may work together to drive the results. For example, a more efficient internal information process would enable government suppliers to gain a better understanding of current performance inside the firm, while a lower level of uncertainty about future demand would make the future sales of government suppliers more predictable. The combination of these two factors would improve the ability of government suppliers to forecast future earnings more 
precisely and more accurately. It remains an open question through which channel(s) contracting with government entities affects the quality of MEFs.

Our analysis is based on one sample of earnings forecasts that were issued by management of government suppliers and corporate suppliers. This research design is susceptible to the self-selection issue and the associated endogeneity challenge because, if our sample is biased, the statistical findings derived from this sample do not represent the population difference in the MEFs between government suppliers and corporate suppliers. Two selection problems in this setting may cause biased representation in our sample. First, firms voluntarily choose to issue MEFs. If firms that have a better capability of gathering information and preparing for earnings forecasts are more likely to issue MEFs, the proportion of such firms in our sample is likely to be higher than that in the population. However, our calculation shows that the corporate suppliers in our sample provide, on average, 3.53 quarterly earnings forecasts in a year, while the government suppliers in our sample provide, on average, 3.34 quarterly earnings forecasts in a year. The difference in forecast frequency between these two groups of suppliers in our sample is not statistically significant at any conventional level of significance. This suggests that among all the firms that issue MEFs, there is no systematic reason why our sample has a larger proportion of government suppliers relative to the population.

The second selection problem is that government entities choose certain types of firms as government suppliers, which causes government suppliers to be different from corporate suppliers in the first place. Also, business dealings between suppliers and government entities over time reinforce the gap between government suppliers and corporate suppliers, as suppliers make relationship-specific investments that cater for their major customers. The extant studies by Cohen and Li (2020), Mills et al. (2013), and Samuels (in press), among others, report empirical evidence on the differences between government suppliers and corporate suppliers. This raises the endogeneity concern of whether our findings that support the influence of major government customers on the quality of supplier MEFs are driven by some systematic differences between government suppliers and corporate suppliers.

Some elements in our research design address this concern. First, we identify government suppliers and corporate suppliers based on a very restrictive definition, that is, government suppliers must report only major government customers in three consecutive years, while corporate suppliers must report only major corporate customers in three consecutive years. This ensures that the differences between government suppliers and corporate suppliers are likely to be persistent over a relatively long time period. Switching between these two groups might cause temporal variation in the differences between these two groups.

Second, as far as we can, we identify the variables that may be related to the differences between these two groups of suppliers and control them in the regression analysis. For example, we find significant differences between the two groups in sales growth, profitability, return volatility, firm age, demand uncertainty, and product market competition, etc. However, none of these variables explain away the government influence on the quality of MEFs in the regressions.

Third, we divide our sample into three subsamples by the MEF surprise. The surprise in each management forecast of quarterly earnings is determined at the time of 
forecast. Whether it is a negative surprise or a positive surprise is unlikely to be related to any persistent difference between the two groups of suppliers. Hence, the grouping of MEFs into these three subsamples is close to an ideal randomization test with regard to the factors that drive the persistent difference between the two groups of firms. We find that government influence is stronger in the negative surprise subsample than in the positive surprise subsample. This is consistent with the ex-ante expectation that management will be more cautious in issuing negative earnings forecasts because of accounting conservatism and litigation risk (Basu 1997; Skinner 1994). If any persistent difference between the two groups of suppliers explains the government influence on the quality of the MEFs, it should show up in both the negative surprise subsample and the positive surprise subsample.

Fourth, we study three characteristics of management forecasts, namely, forecast precision, forecast accuracy, and price impact. Managers have direct control in determining forecast precision but relatively less control over forecast accuracy. We find that the influence of major government customers is stronger on forecast precision than on forecast accuracy. Again, this cannot be explained by a persistent factor that distinguishes government suppliers from corporate suppliers, if major government customers do not have a significant influence on the quality of MEFs. Although we do not have a direct test that addresses the endogeneity concern, the consistency in our findings across subsamples and different measures of forecast quality suggests that contracting with the U.S. government is associated with noticeable improvement in the quality of supplier MEFs.

\section{Summary and conclusion}

In this paper, we investigate whether customer base composition, i.e., whether a firm's major customer is the government or publicly traded firms in the U.S., affects the properties of a firm's MEFs. Government as a major customer is unique in many ways and has not been thoroughly studied in the supply chain literature. We conjecture that firms with major government customers enjoy lower operating uncertainty and are enabled to improve the quality of the information they provide to the capital market.

Our empirical analyses show a strong government effect on the quality of MEFs. Specifically, we find that government suppliers issue more precise MEFs than corporate suppliers. In addition, government suppliers issue more accurate MEFs than corporate suppliers. However, when MEFs match analysts' consensus forecasts, the difference in forecast accuracy between the two groups of suppliers disappears. Moreover, when managers disclose negative information to the market, earnings forecasts issued by government suppliers have greater price impact than those issued by corporate suppliers.

Our study contributes to the literature by showing how firms with different customer base compositions exhibit different properties in the information they voluntarily disclose to the capital market. The recent literature documents evidence of managerial self-interests that influence the issuance and quality of MEFs. For example, managers guide investor expectations, time the issuance of management forecasts strategically, and bundle management forecasts with earnings announcements. We call for future research to explore whether contracting with government entities helps to alleviate the influence of such self-centered managerial motives on MEFs. 


\section{Acknowledgements}

We would like to thank three anonymous reviewers, Grace Pownall, Katherine Schipper, Lili Shao, Naomi Soderstrom, Nianhang Xu, Shuye Wang, and seminar participants at Renmin University of China, the 2018 International Conference in Accounting, Finance, Economics and Law (ICAFEL), the 2018 China International Risk Forum, and the 2019 Financial Management Association (FMA) European Conference for helpful comments. We also thank Weijia Hu, Mengke Lu, Lingyi Zheng, and Yuxiang Zhong for research assistance.

\section{Authors' contributions}

All three authors play an equally important role in the completion of the manuscript. The author(s) read and approved the final manuscript.

\section{Funding}

We acknowledge the financial support for the research project No. 15507217 by the General Research Fund from the Research Grants Council of the Hong Kong Special Administrative Region Government.

\section{Availability of data and materials}

All datasets used for empirical analysis in the manuscript are commercially available to the public.

\section{Consent for publication}

Not applicable.

\section{Competing interests}

Not applicable.

Received: 3 January 2020 Accepted: 31 July 2020

Published online: 23 September 2020

\section{References}

Ak, B., \& Patatoukas, P. (2016). Customer-base concentration and inventory efficiencies: Evidence from manufacturing sector. Production and Operations Management, 25(2), 258-272.

Baber, W. R., \& Gore, A. K. (2008). Consequences of GAAP disclosure regulation: Evidence from municipal debt issues. The Accounting Review, 83(3), 565-592.

Banerjee, S., Dasgupta, S., \& Kim, Y. (2008). Buyer-supplier relationships and the stakeholder theory of capital structure. Journal of Finance, 63(5), 2507-2552.

Basu, S. (1997). The conservatism principle and the asymmetric timeliness of earnings. Journal of Accounting and Economics, 24(1), 3-37.

Berger, P. G., \& Hann, R. (2003). The impact of SFAS no. 131 on information and monitoring. Journal of Accounting Research, $41(2), 163-223$.

Berrios, R. (2006). Government contracts and contractor behavior. Journal of Business Ethics, 63, 119-130.

Beyer, A.r Cohen, D., Lys, T., \& Walther, B. (2010). The financial reporting environment: Review of the recent literature. Journal of Accounting and Economics, 50(2), 296-343.

Campello, M., \& Gao, J. (2017). Customer concentration and loan contract terms. Journal of Financial Economics, 123(1), 108136.

Cen, L., Maydew, E., Zhang, L., \& Zuo, L. (2017). Customer-supplier relationships and corporate tax avoidance. Journal of Financial Economics, 123(2), 377-394.

Chaney, P. K., Faccio, M., \& Parsley, D. (2011). The quality of accounting information in politically connected firms. Journal of Accounting and Economics, 51(1), 58-76.

Chen, S., Matsumoto, D., \& Rajgopal, S. (2011). Is silence golden? An empirical analysis of firms that stop giving quarterly earnings guidance. Journal of Accounting and Economics, 51(1), 134-150.

Cheng, A. C. S., \& Eshleman, J. D. (2014). Does the market overweight imprecise information? Evidence from customer earnings announcements. Review of Accounting Studies, 19(3), 1125-1151.

Chiu, T. T., Kim, J. B., \& Wang, Z. (2019). Customers' risk factor disclosures and suppliers' investment efficiency. Contemporary Accounting Research, 36(2), 934-957.

Cohen, D. A., \& Li, B. (2020). Customer-base concentration, investment, and profitability: The U.S. government as a major customer. The Accounting Review, 95(1), 101-131.

Cohen, L., \& Frazzini, A. (2008). Economic links and predictable returns. Journal of Finance, 63(4), 1977-2011.

Cohen, L., \& Malloy, C.J. (2016). Mini West Virginias: Corporations as government dependents. Available at SSRN: https://ssrn. $\mathrm{com} / \mathrm{abstract}=2758835$.

Costello, A. M. (2013). Mitigating incentive conflicts in inter-firm relationships: Evidence from long-term supply contracts. Journal of Accounting and Economics, 56(1), 19-39.

Crawford, S., Huang, Y., Li, N., \& Yang, Z. (2020). Customer concentration and public disclosure: Evidence from management earnings and sales forecasts. Contemporary Accounting Research, 37(1), 131-159.

Dhaliwal, D., Judd, S., Serfling, M., \& Shaikh, S. (2016). Customer concentration risk and the cost of equity capital. Journal of Accounting and Economics, 61(1), 23-48.

Dhaliwal, D., Michas, P., Naiker, V., \& Sharma, D. (2020). Greater reliance on major customers and auditor going concern opinions. Contemporary Accounting Research, 37(1), 160-188.

Ellis, J. A., Fee, C. E., \& Thomas, S. E. (2012). Proprietary costs and the disclosure of information about customers. Journal of Accounting Research, 50(3), 685-727.

Fama, E., \& French, K. (1997). Industry costs of equity. Journal of Financial Economics, 43(2), 153-193.

Fee, C. E., Hadlock, C. J., \& Thomas, S. E. (2006). Corporate equity ownership and the governance of product market relationships. Journal of Finance, 61(3), 1217-1251. 
Fee, C. E., \& Thomas, S. E. (2004). Sources of gains in horizontal mergers: Evidence from customer, supplier, and rival firms. Journal of Financial Economics, 74(3), 423-460.

Goldman, E., Rocholl, J., \& So, J. (2013). Politically connected boards of directors and the allocation of procurement contracts. Review of Finance, 17(5), 1617-1648.

Gore, A. K. (2004). The effects of GAAP regulation and bond market interaction on local government disclosure. Journal of Accounting and Public Policy, 23(1), 23-52.

Guiso, L., \& Parigi, G. (1999). Investment and demand uncertainty. Quarterly Journal of Economics, 114(1), 185-227.

Healy, P. M., \& Palepu, K. G. (2001). Information asymmetry, corporate disclosure, and the capital markets: A review of the empirical disclosure literature. Journal of Accounting and Economics, 31(1), 405-440.

Hirst, D. E., Koonce, L., \& Venkataraman, S. (2008). Management earnings forecasts: A review and framework. Accounting Horizons, 22(3), 315-338.

Huang, Y., Jennings, R., \& Yu, Y. (2017). Product market competition and managerial disclosure of earnings forecasts: Evidence from import tariff rate reductions. The Accounting Review, 92(3), 185-207.

Hui, K. W., Klasa, S., \& Yeung, P. E. (2012). Corporate suppliers and customers and accounting conservatism. Journal of Accounting and Economics, 53(1), 115-135.

Hui, K. W., Liang, C., \& Yeung, P. E. (2019). The effect of major customer concentration on firm profitability: Competitive or collaborative? Review of Accounting Studies, 24, 189-229.

Irvine, P. J., Park, S., \& Yildizhan, C. (2016). Customer-based concentration, profitability, and the relationship life cycle. The Accounting Review, 91(3), 883-906.

Itzkowitz, J. (2013). Customers and cash: How relationships affect suppliers' cash holdings. Journal of Corporate Finance, 19, 159-180.

Kale, J. R., \& Shahrur, H. (2007). Corporate capital structure and the characteristics of suppliers and customers. Journal of Financial Economics, 83(2), 321-365.

Kasznik, R., \& Lev, B. (1995). To warn or nor to warn: Management disclosures in the face of an earnings surprise. The Accounting Review, 70(1), 113-134.

Kim, J. B., Song, B. Y., \& Zhang, Y. (2015). Earnings performance of major customers and bank loan contracting with suppliers. Journal of Banking and Finance, 59, 384-398.

Krishnan, G. V., Patatoukas, P. N., \& Wang, A. Y. (2019). Customer-base concentration: Implications for audit pricing and quality. Journal of Management Accounting Research, 31(1), 129-152.

Leuz, C., \& Wysocki, P. D. (2016). The economics of disclosure and financial reporting regulation: Evidence and suggestions for future research. Journal of Accounting Research, 54(2), 525-622.

$\mathrm{Li}, \mathrm{X}$. (2010). The impacts of product market competition on the quantity and quality of voluntary disclosures. Review of Accounting Studies, 15, 663-711.

Mills, L. F., Nutter, S. E., \& Schwab, C. M. (2013). The effect of political sensitivity and bargaining power on taxes: Evidence from federal contractors. The Accounting Review, 88(3), 977-1005.

Pandit, S., Wasley, C. E., \& Zach, T. (2011). Information externalities along the supply chain: The economic determinants of suppliers' stock price reaction to their customers' earnings announcements. Contemporary Accounting Research, 28(4), 1304-1343.

Patatoukas, P. N. (2012). Customer-base concentration: Implications for firm performance and capital markets. The Accounting Review, 87(2), 363-392.

Radhakrishnan, S., Wang, Z., \& Zhang, Y. (2014). Customers' capital market information quality and supplier's performance. Production and Operations Management, 23(10), 1690-1705.

Raman, K., \& Shahrur, H. (2008). Relationship-specific investments and earnings management: Evidence on corporate suppliers and customers. The Accounting Review, 83(4), 1041-1081.

Samuels, D. (in press). Government procurement and changes in firm transparency. The Accounting Review.

Shroff, N., Verdi, R. S., \& Yost, B. P. (2017). When does the peer information environment matter? Journal of Accounting and Economics, 64(2), 183-214.

Skinner, D. (1994). Why firms voluntarily disclose bad news. Journal of Accounting Research, 32(1), 38-60.

Skinner, D. (1997). Earnings disclosures and stockholder lawsuits. Journal of Accounting and Economics, 23(3), 249-282.

Verrecchia, R. (1983). Discretionary disclosure. Journal of Accounting and Economics, 5, 179-194.

Verrecchia, R. (1990). Information quality and discretionary disclosure. Journal of Accounting and Economics, 12(4), 365-380

Wang, J. (2012). Do firms' relationships with principal customers/suppliers affect shareholders' income? Journal of Corporate Finance, 18(4), 860-878.

\section{Publisher's Note}

Springer Nature remains neutral with regard to jurisdictional claims in published maps and institutional affiliations. 